\title{
GUIDE TO FURTHER READING
}

\section{General}

Arnold, David (ed.) Imperial Medicine and Indigenous Societies. Manchester: Manchester University Press, 1988.

Bannerman, R. H., J. Burton, and Wen-chieh Ch'en, eds. Traditional Medicine and Health Care Coverage: a Reader for Health Administrators and Practitioners. Geneva: World Health Organization, 1983.

Brockway, Lucile H. Science and Colonial Expansion: the Role of the British Royal Botanic Gardens. New York and London: Academic Press, 1979.

Bynum, W. F., and Roy Porter (eds) Companion Encyclopedia of the History of Medicine. London: Routledge, 1993.

Chakrabarty, Dipesh. 'Postcoloniality and the artifice of history: who speaks for "Indian" pasts?' Representations 37 (1992): 1-26.

Etherington, Norman. Theories of Imperialism: War, Conquest and Capital. London: Croom Helm, 1984.

Headrick, Daniel R. The Tentacles of Progress: Technology Transfer in the Age of Imperialism, 1850-1940. Oxford: Oxford University Press, 1988.

Hessenbruch, Arne (ed.) Reader's Guide to the History of Science. London: Fitzroy Dearborn, 1996.

Horton, Robin. 'African traditional thought and Western science.' Africa 37 (1967): 50-71 and 155-87.

Howard-Jones, Norman. The Scientific Background of the International Sanitary Conferences, 1851-1938. Geneva: World Health Organization, 1975.

Kuper, Adam. The Invention of Primitive Society: Transformations of an Illusion. London: Routledge, 1988.

Landy, David (ed.) Culture, Disease and Healing: Studies in Medical Anthropology. New York: Macmillan, 1977.

Lindenbaum, Shirley, and Margaret Lock (eds) Knowledge, Power and Practice: the Anthropology of Medicine and Everyday Life. Berkeley, Cal.: University of California Press, 1993.

MacLeod, Roy, and Milton Lewis (eds) Disease, Medicine, and Empire: Perspectives on Western Medicine and the Experience of European Expansion. London and New York: Routledge, 1988.

Nandy, Ashis (ed.) Science, Hegemony and Violence: a Requiem for Modernity. Delhi and Oxford: Oxford University Press, 1988.

Said, Edward W. Orientalism. Harmondsworth: Penguin Books (1978) 1985.

Stocking, George (ed.) 'Colonial situations: essays on the contextualization of ethnographical knowledge.' History of Anthropology 7 (1991): 3-8.

Science and Empire Newsletter. Joint publication of NISTADS (New Delhi) and REHSEIS (Paris). 


\section{WESTERN MEDICINE AS CONTESTED KNOWLEDGE}

\section{India}

Arnold, David. Colonizing the Body: State Medicine and Epidemic Disease in Nineteenth-century India. Berkeley and Los Angeles: University of California Press, 1993.

Bala, Poonam. Imperialism and Medicine in Bengal: a Sociohistorical Perspective. New Delhi: Sage, 1991.

Catanach, Ian. 'Plague and the tensions of empire: India, 1896-1918' in Imperial Medicine and Indigenous Societies (ed.) David Arnold. Manchester: Manchester University Press, 1988.

Chandavarkar, Rajnarayan. 'Plague panic and epidemic politics in India, 1896-1914' in Epidemics and Ideas: Essays on the Historical Perception of Pestilence (ed.) Terence Ranger and Paul Slack. Cambridge: Cambridge University Press, 1992.

Guha, Ranajit (ed.) Subaltern Studies.

Harrison, Mark. Public Health in British India. Cambridge History of Medicine (ed.) Charles Webster and Charles Rosenberg. Cambridge: Cambridge University Press, 1994.

Klein, Ira. 'Plague policy and popular unrest in British India'. Modern Asian Studies 22 (4 1988): 723-55.

Kumar, Deepak (ed.) Science and Empire: Essays in Indian Context, 1700 1947. Delhi: Anamika Prakashan, 1991.

Kumar, Deepak. Science and the Raj, 1857-1905. Delhi and Oxford: Oxford University Press, 1995.

Prakash, Gyan. 'Science "gone native" in colonial India.' Representations 40 (1992): 153-78.

Sangwan, Satpal. Science, Technology and Colonisation: an Indian Experience, 1757-1857. New Delhi: Anamika Prakashan, 1991.

\section{Africa}

Chirimuuta, Richard, and Rosalind Chirimuuta. AIDS, Africa and Racism. Second edition, London: Free Association Books, 1989.

Feierman, Steven, and John M. Janzen (eds) The Social Basis of Health and Healing in Africa. Berkeley and Los Angeles: University of California Press, 1992.

Gallagher, Nancy E. Medicine and Power in Tunisia, 1780-1900. Cambridge: Cambridge University Press, 1983.

Janzen, John M., and Gwyn Prins (eds) 'Causality and classification in African medicine and health.' Special issue of Social Science and Medicine 15b (1981).

Lyons, Maryinez. The Colonial Disease: a Social History of Sleeping Sickness in Northern Zaire, 1900-40. Cambridge: Cambridge University Press, 1992.

Vaughan, Megan. Curing their Ills: Colonial Power and African Illness. Cambridge: Polity Press, 1991. 


\section{GUIDE TO FURTHER READING}

Vaughan, Megan. 'Healing and curing: issues in the social history and anthropology of medicine in Africa.' Social History of Medicine 7 (2 1994): 283-95.

\section{East Asia}

Bowers, John Z. When the Twain Meet: the Rise of Western Medicine in Japan. Baltimore: Johns Hopkins University Press, 1980.

Croizier, Ralph C. Traditional Medicine in Modern China: Science, Nationalism and the Tensions of Cultural Change. Cambridge, Mass.: Harvard University Press, 1968.

Farquhar, Judith. Knowing Practice: the Clinical Encounter of Chinese Medicine. Boulder, Colo.: Westview Press, 1994.

Kleinman, Arthur K. Patients and Healers in the Context of Culture: an Exploration of the Borderland between Anthropology, Medicine and Psychiatry. Berkeley: University of California Press, 1980.

Kuriyama, Shigehisa. 'Between mind and eye: Japanese anatomy in the eighteenth century' in Paths to Asian Medical Knowledge (ed.) Charles Leslie and Allan Young. Berkeley: University of California Press, 1992.

Nathan, Carl F. 'The acceptance of Western medicine in early twentieth century China: the story of the North Manchurian Plague Prevention Service', in Medicine and Society in China (ed.) John Z. Bowers and Elizabeth F. Purcell. Philadelphia: Wm F. Fell for the National Library of Medicine and the Josiah Macy, Jr, Foundation, 1974.

Ohnuki-Tierney, Emiko. Illness and Culture in Contemporary Japan: an Anthropological View. Cambridge: Cambridge University Press, 1984.

Owen, N. G. (ed.) Death and Disease in South Asia: Explorations in Social, Medical and Demographic History. Singapore: Oxford University Press, 1987.

Sivin, Nathan. Traditional Medicine in Contemporary China. Ann Arbor: Center for Chinese Studies, University of Michigan, 1987.

Thomson, James C., Jr. While China Faced West: American Reformers in Nationalist China, 1928-37. Cambridge, Mass.: Harvard University Press, 1969.

Watanabe, Masao. The Japanese and Western Science. Translated by O. T. Benfey, Philadelphia: University of Pennsylvania Press, 1990.

Zito, Angela, and Tani E. Barlow (eds) Body, Subject and Power in China. Chicago: University of Chicago Press, 1994.

\section{The Americas}

Birn, Anne-Emmanuelle. 'Local health and foreign wealth: the Rockefeller Foundation's public health programs in Mexico, 1924-51.' Sc.D., The Johns Hopkins University, 1993. 
Cueto, Marcos (ed.) Missionaries of Science: the Rockefeller Foundation and Latin America. Bloomington, Ind.: Indiana University Press, 1994.

Ettling, John. The Germ of Laziness: Rockefeller Philanthropy and Public Health in the New South. Cambridge Mass.: Harvard University Press, 1981.

Kunitz, Stephen. Disease and Social Diversity: the European Impact on the Health of Non-Europeans. New York: Oxford University Press, 1994.

Solórzano, Armando. 'The Rockefeller Foundation in Mexico: nationalism, public health, and yellow fever.' Ph.D., University of WisconsinMadison, 1990. 